\title{
Serum levels of brain-derived neurotrophic factor in acute and posttraumatic stress disorder: a case report study
} Nivel sérico do fator neurotrófico derivado do cérebro no transtorno de estresse agudo e no transtorno de estresse pós-traumático: relato de casos

\author{
Simone Hauck ${ }^{1,2}$, Fabiano Gomes $^{3}$, Érico de Moura Silveira Júnior ${ }^{1,2}$, \\ Ellen Almeida ${ }^{1}$, Marianne Possa ${ }^{1}$, Lúcia Helena Freitas Ceitlin ${ }^{1,2}$
}

\begin{abstract}
Objective: The aim of this study was to evaluate brain-derived neurotrophic factor levels in two patients, one with posttraumatic stress disorder and one with acute stress disorder, before and after treatment, and to compare those levels to those of healthy controls. Method: Brain-derived neurotrophic factor level, Davidson Trauma Scale, Beck Depression Inventory, Global Assessment of Functioning, and Clinical Global Impression were assessed before and after 6 weeks of treatment. Results: Brain-derived neurotrophic factor levels were higher in patients than in matched controls before treatment. After 6 weeks, there was a reduction in symptoms and an improvement in functioning in both cases. At the same time, brain-derived neurotrophic factor levels decreased after treatment, even in case 2, treated with psychotherapy only. Conclusions: These results suggest that serum levels of brain-derived neurotrophic factor, as opposed to what has been described in mood disorders, are increased in posttraumatic stress disorder as well as in acute stress disorder.
\end{abstract}

Descriptors: Stress disorders, posttraumatic; Stress disorders, traumatic, acute; Brain-derived neurotrophic factor; Treatment outcome; Case studies

\section{Resumo}

Objetivo: O objetivo do estudo foi avaliar os níveis séricos do fator neurotrófico derivado do cérebro em um paciente com transtorno de estresse pós-traumático e em um paciente com transtorno de estresse agudo antes e após o tratamento, comparando esses níveis aos de controles saudáveis. Método: Os níveis do fator neurotrófico derivado do cérebro, a Escala Davidson de Trauma, o Inventário de Depressão de Beck, a Avaliação do Funcionamento Global e a Impressão Clínica Global foram medidos antes e após seis semanas de tratamento. Resultados: Os níveis de fator neurotrófico derivado do cérebro foram maiores nos pacientes, quando comparados aos controles, antes do tratamento. Depois de seis semanas houve redução dos sintomas e melhora do funcionamento nos dois casos. Ao mesmo tempo, houve redução dos níveis de fator neurotrófico derivado do cérebro, mesmo no caso 2, tratado exclusivamente com psicoterapia. Conclusóes: Esses resultados sugerem que o fator neurotrófico derivado do cérebro está aumentado tanto no transtorno de estresse pós-traumático quanto no transtorno de estresse agudo, de forma oposta às alterações até então descritas nos transtornos do humor.

Descritores: Transtornos de estresse pós-traumático; Transtornos de estresse traumático agudo; Fator neurotrófico derivado do encéfalo; Resultado de tratamento; Estudo de casos

\footnotetext{
1 Center for Study and Treatment of Traumatic Stress, Hospital de Clínicas de Porto Alegre (HCPA), Porto Alegre (RS), Brazil

2 Universidade Federal do Rio Grande do Sul (UFRGS), Porto Alegre (RS), Brazil

3 Bipolar Disorders Program and Laboratory of Molecular Psychiatry, Hospital de Clínicas de Porto Alegre (HCPA), Porto Alegre (RS), Brazil
}

Ethical aspects: The protocol of this project was fully approved by the Health Research Ethics Committee of the Research and Graduate Study Group of HCPA under the register GPPG 06-649, as well as the free and informed consent forms that were signed by all patients and therapists who took part in the study. 


\section{Introduction}

In the last decades, the role of neurotrophic factors, especially the brain-derived neurotrophic factor (BDNF), has been extensively studied. Central during early life development, BDNF has been implicated in several aspects of the central nervous system (CNS) functioning in adulthood, such as those related to neuronal plasticity, neurogenesis and response to brain insults. Lower levels of BDNF have been reported in mood disorders, and psychotropic medications such as serotonin reuptake inhibitors and mood stabilizers seem to increase BDNF levels ${ }^{1,2}$.

Traumatic situations and associated psychopathology, especially posttraumatic stress disorder (PTSD), have been consistently associated with hippocampal reduction. These findings have been related to apoptotic mechanisms, leading to stress-induced cell death in the hippocampus ${ }^{3}$, which could partially explain PTSD symptoms, resulting in impaired memory and learning. Studies with animal models have demonstrated a reduction in BDNF mRNA in the hippocampal dentate gyrus after exposure to trauma; this reduction was even greater after re-exposure ${ }^{4}$. However, one study with adult animals that had early adversities showed increased levels of neurotrophic factors (BDNF, NGT and NT-3) in the dorsal and ventral hippocampus, leading to the hypothesis of a compensatory mechanism ${ }^{5}$. According to Tapia-Arancibia, neurotrophins, and particularly BDNF, may have a major protective role against neuronal damage by stimulation of sprouting and synaptic reorganization, promoting resilience of brain cells to cope with stressful challenges ${ }^{2}$.

As far as we are aware, there are no data regarding BDNF levels in patients with PTSD. Kauer-Sant'Anna et al. demonstrated lower BDNF plasma levels in bipolar patients with history of trauma exposure, controlling for other variables, such as mood status, leading to the hypothesis of an independent effect of trauma exposure on BDNF levels ${ }^{6}$. Thus, we hypothesized a priori that patients with acute stress disorder (ASD) and PTSD symptoms would have lower BDNF levels than healthy controls, and that those levels would increase, along with a reduction in symptoms, with an effective treatment. Accordingly, the aim of this study was to evaluate BDNF serum levels in one PTSD and in one ASD patient before and after treatment, and to compare those levels to the levels of healthy controls.

\section{Case reports}

Patients were evaluated by qualified psychiatrists in the Center for Study and Treatment of Traumatic Stress of Hospital de Clínicas de Porto Alegre - Brazil. The diagnosis was made according to DSM-IV-TR criteria. The severity of PTSD symptoms was assessed by means of the Davidson Trauma Scale (DTS) ${ }^{7}$, and the symptoms of depression were assessed by means of the Beck Depression Inventory $(\mathrm{BDI})^{8}$. The Clinical Global Impression was inferred by CGI-S, and global functioning by Global Assessment of Functioning $(\mathrm{GAF})^{9}$. Blood samples were collected from each subject by venipuncture at baseline (time 0) and after 7 weeks (time 1). Blood was immediately centrifuged at 3000x g for 5 min, and serum was kept frozen at -80 o $\mathrm{C}$ until assayed. BDNF serum levels were measured with sandwich-ELISA, using a commercial kit according to the manufacturer's instruction (Chemicon, Temecula, CA). Total protein was measured with Lowry's method using bovine serum albumin as standard. All subjects provided a written informed consent prior to their enrollment in the study. This study was approved by the local Research Ethics Committee (Hospital de Clínicas de Porto Alegre, Porto Alegre - Brazil).

\section{Case 1 (PTSD)}

Female, 24 years old, single, 11 years of education, currently working, and with good social background. The patient suffered repeated sexual abuses in childhood. Her father usually presented an aggressive pattern of behavior, and was the first perpetrator. She reported a good relationship with her mother. The patient referred persistent PTSD symptoms for several years. Although there were symptoms consistent with comorbidity with major depression disorder (MDD) in the evaluation interview, and high scores on the $\mathrm{BDI}$, according to the assessment measures, the patient did not present a history of other psychiatric diagnosis besides PTSD in the past. After assessment, she was treated with six sessions of brief psychotherapy plus 150 mg sertraline (which she had started 15 days before the first evaluation).

\section{Case 2 (ASD)}

Female, 48 years, divorced, 11 years of education, currently working, and with good social background. The patient was robbed 17 days before the evaluation assessment. The attacker had broken into her house and threatened her with physical aggression. She denied previous trauma, or a history of other psychiatric disorders, except for a small period of substance abuse in the past, which was successfully treated with group therapy. She was taking no psychotropic medication at baseline (time 0), and presented symptoms of ASD. Treatment consisted of six sessions of brief psychotherapy.

Health controls were matched for age, gender and education. Control subjects were not on medication and had no history of major psychiatric disorders, dementia and mental retardation. Also, those disorders were not present in their first-degree relatives.

\section{Results and discussion}

At baseline (time 0), both patients presented remarkably increased levels of BDNF (time 0), when compared to age- and gender-matched healthy controls. All clinical parameters (DTS, BDI, GAF and CGI) substantially improved after 6 weeks of treatment, concomitantly with an important decrease in BDNF levels (Table 1 ). Case 2 (ASD) had the largest rate of improvement, reaching remission levels in all parameters. In the same way, the rate of decrease of BDNF levels was more than twice higher for case 2 (64.9\%), when compared with case 1 (25.3\%). It is of great interest to note that both psychopharmacologic and psychotherapeutic treatment led to a reduction in BDNF levels. As far as we know, there are no data regarding BDNF levels as an outcome of psychotherapy described in the present literature. Surprisingly, ASD and PTSD were related to increased BDNF levels in our two cases. Furthermore, improvement in clinical conditioning was associated with a decrease in those levels. This finding was evident even in case 1 , a chronic PTSD condition secondary to childhood sexual abuse, associated with important depressive symptoms.

Traumatic life events, and particularly sexual abuse, have been associated with lower BDNF levels in bipolar patients, but it is noteworthy that this association was not related to the diagnosis of $\mathrm{PTSD}^{6}$. It is possible that traumatic exposure did not account directly for the increase in BDNF levels. In fact, without ASD or PTSD psychopathology, it could be related to lower levels of BDNF in vulnerable subjects as suggested by other authors. One could hypothesize that ASD and PTSD could represent particular conditions, in which traumatic situations could not be handled in CNS in terms of returning to a homeostatic state. In fact, animal studies have pointed to an increase in hippocampal BDNF mRNA in 
Table 1 - Clinical and BDNF parameters in patients and controls

\begin{tabular}{lcccccc}
\hline & BDNF $(\mathbf{p g} / \mathbf{m l})$ & CGI & GAF & DTS-F & DTS-S & DTS-T \\
\hline Control 1 & 0.32 & N/A & N/A & N/A & N/A & N/A \\
Case 1 (PTSD) & & & & & & \\
Time 0 & 0.83 & 5 & 50 & 54 & 56 & 110 \\
Time 1 & 0.62 & 3 & 70 & 37 & 41 & 78 \\
Control 2 & 0.34 & N/A & N/A & N/A & N/A & N/A \\
Case 2 (ASD) & & & & & & \\
Time 0 & 0.57 & 5 & 60 & 32 & 24 & 56 \\
Time 1 & 0.20 & 2 & 80 & 4 & 4 & \\
\hline
\end{tabular}

BDNF = Brain-Derived Neurotrophic Factor; CGI = Clinical Global Impression Scale; GAF = Global Assessment Functioning; DTS-F = Davidson Trauma Scale frequency of symptoms; DTS-S = Davidson Trauma Scale - severity of symptoms; DTS-T = Davidson Trauma Scale - Total scores; BDI = Beck Depression Inventory.

shorter periods of stress, but that compensatory response is lost after exposure to longer periods of stress, leading to decreased BDNF levels. This shift towards a decrease in BDNF could have other homeostatic purpose such as preventing a repeated neuronal stimulation, which could result in receptor desensitization or tissue damage ${ }^{2,10}$.

Increased levels of BDNF mRNA and protein content in ASD and PTSD could resemble those found in epileptic conditions. If some authors suggest a resilient compound of BDNF increase after seizures related to neuroprotection, others have pointed to a possible pathogenic mechanism, resulting in epileptogenesis, due to synaptic effects on excitability, and also by inducing changes in dendritic or axonal sprouting, synaptic morphology and synapse formation ${ }^{2}$. Another interesting possibility is related to lower cortisol levels in response to stress and dexamethasone test, systematically observed in subjects with PTSD ${ }^{11}$. This finding is exactly the opposite in mood disorders, and could partially explain the shift to an opposite direction of BDNF in PTSD. The larger reduction rate in BDNF and clinical parameters in case 2 could be related to a more acute condition, and a potential less traumatic situation. One could also think of greater resilience in case 2 due to constitutional and environmental factors.

\section{Conclusions}

Our results must be interpreted with caution since this is a preliminary report about the role of BDNF in patients with PTSD and ASD. It is important to replicate these findings with larger samples and longer follow-up periods. Actually, it is also possible that an increase in BDNF reflects an attempt to compensate for other neurobiological alterations that occur in PTSD and ASD.

Another interesting finding is that BDNF level markedly decreased in case 2, treated exclusively with psychotherapy, along with the improvement of clinical parameters. As far as we know, there are no studies showing changes in BDNF level with psychotherapy, and this question could be addressed in future studies.

One limitation of our study is that BDNF levels were measured in serum. Although there is evidence showing a high correlation between serum and cortical BDNF levels $(r=0.81)$, it is not possible to infer that our findings reflect only brain-related psychopathology.

\section{Acknowledgements}

We thank Prof. Sidnei Schestatsky (Universidade Federal do Rio Grande do Sul, Psychiatry Department) for his permanent support to our work; Letícia Kruel, Caroline Machado, Débora Schaf and Eduardo Bornmann for their assistance with patients and research; Laura Stertz, student of biomedicine (UFRGS), for the assistance with the biochemistry dosages; and Prof. Flavio Kapczinski (Universidade Federal do Rio Grande do Sul, Psychiatry Department) for the thoughtful comments on the study design and writing of the manuscript.

\section{Disclosures}

\begin{tabular}{|c|c|c|c|c|c|c|c|}
\hline $\begin{array}{l}\text { Writting group } \\
\text { member }\end{array}$ & Employment & Research grant $^{1}$ & $\begin{array}{l}\text { Other research grant or } \\
\text { medical continuous } \\
\text { education }\end{array}$ & $\begin{array}{l}\text { Speaker's } \\
\text { honoraria }\end{array}$ & $\begin{array}{l}\text { Ownership } \\
\text { interest }\end{array}$ & $\begin{array}{l}\text { Consultant/ } \\
\text { Advisory } \\
\text { board }\end{array}$ & Other $^{3}$ \\
\hline Simone Hauck & $\mathrm{HCPA}$ & FIPE- HCPA* & -- & --- & --- & --- & --- \\
\hline Fabiano Gomes & $\mathrm{HCPA}$ & FIPE- HCPA* & --- & --- & --- & --- & --- \\
\hline $\begin{array}{l}\text { Érico de Moura } \\
\text { Silveira Júnior }\end{array}$ & HCPA & FIPE- HCPA* & -- & -- & -- & -- & --- \\
\hline Ellen Almeida & $\mathrm{HCPA}$ & -- & -- & -- & -- & -- & -- \\
\hline Marianne Possa & HCPA & --- & --- & --- & --- & --- & --- \\
\hline $\begin{array}{l}\text { Lúcia Helena } \\
\text { Freitas Ceitlin }\end{array}$ & $\begin{array}{l}\text { HCPA } \\
\text { UFRGS }\end{array}$ & FIPE- HCPA* & --- & -- & -- & --- & --- \\
\hline
\end{tabular}

\section{* Modest}

** Significant

*** Significant. Amounts given to the author's institution or to a colleague for research in which the author has participation, not directly to the author.

Note: HCPA = Hospital de Clínicas de Porto Alegre; UFRGS = Universidade Federal do Rio Grande do Sul; FIPE-HCPA = Fundo de Incentivo à Pesquisa do Hospital de Clínicas de Porto Alegre.

For more information, see Instructions for authors. 


\section{References}

1. Post RM. Role of BDNF in bipolar and unipolar disorder: clinical and theoretical implications. J Psychiatr Res. 2007;41(12):979-90.

2. Tapia-Arancibia L, Rage F, Givalois L, Arancibia S. Physiology of BDNF: focus on hypothalamic function. Front Neuroendocrinol. 2004;25(2):77-107.

3. Zhang L, Zhou R, Li X, Ursano RJ, Li H. Stress-induced change of mitochondria membrane potential regulated by genomic and non-genomic GR signaling: a possible mechanism for hippocampus atrophy in PTSD. Med Hypotheses. 2006;66(6):1205-8.

4. Rasmusson AM, Shi L, Duman R. Downregulation of BDNF mRNA in the hippocampal dentate gyrus after re-exposure to cues previously associated with footshock. Neuropsychopharmacology. 2002;27(2):133-42.

5. Faure J, Uys JD, Marais L, Stein DJ, Daniels WM. Early maternal separation alters the response to traumatization: resulting in increased levels of hippocampal neurotrophic factors. Metab Brain Dis. 2007;22(2):183-95.

6. Kauer-Sant'Anna M, Tramontina J, Andreazza AC, Cereser K, da Costa S, Santin A, Yatham LN, Kapczinski F. Traumatic life events in bipolar disorder: impact on BDNF levels and psychopathology. Bipolar Disord. 2007;9 Suppl 1:128-35.

7. Davidson JR, Malik MA, Travers J. Structured interview for PTSD (SIP): psychometric validation for DSM-IV criteria. Depress Anxiety. 1997;5(3): 127-9.

8. Gorenstein C, Andrade L. Validation of a Portuguese version of the Beck Depression Inventory and the State-Trait Anxiety Inventory in Brazilian subjects. Braz J Med Biol Res. 1996;29(4):453-7.

9. American Psychiatry Association. Diagnostic and Statistical Manual of Mental Disorders. 4a ed. Washington, DC: American Psychiatric Association; 1994.

10. Lee R, Kermani P, Teng KK, Hempstead BL. Regulation of cell survival by secreted proneurotrophins. Science. 2001;294(5548):1945-8.

11. Yehuda R, Morris A, Labinsky E, Zemelman S, Schmeidler J. Ten-year follow-up study of cortisol levels in aging holocaust survivors with and without PTSD. J Trauma Stress. 2007;20(5):757-61. 